\title{
A New Model Describing Copper Dose-Toxicity to Tomato and Bok Choy Growth in a Wide Range of Soils
}

\author{
Bao Jiang ${ }^{1}$, Yibing $\mathrm{Ma}^{1, *}$, Guangyun $\mathrm{Zhu}^{2}$ and ${\mathrm{Jun} \mathrm{Li}^{1,3}}^{1,3}$ \\ 1 Institute of Agricultural Resources and Regional Planning, Chinese Academy of Agricultural Sciences, \\ Beijing 100081, China; jiangbao@caas.cn (B.J.); lijun01@caas.cn (J.L.) \\ 2 School of Resources and Environment, University of Jinan, Jinan 250022, China; zhuguangyun1993@163.com \\ 3 Laboratory of Quality and Safety Risk Assessment for Microbial Products (Beijing), Ministry of Agriculture, \\ Beijing 100081, China \\ * Correspondence: mayibing@caas.cn; Tel.: +86-10-8210-6201
}

Received: 25 December 2018; Accepted: 15 January 2019; Published: 18 January 2019

\begin{abstract}
Phytotoxicity thresholds for heavy metals are derived from dose-response curves, which show the relationships between exposure dose and toxicity response. However, the results of tests or observations are commonly based on total heavy metal concentration, not the exposure dose that causes phytotoxicity; additionally, the phytotoxicity response differs with plant species. In the present study, the ethylenediaminetetraacetic acid (EDTA)-extractable copper $(\mathrm{Cu})$ concentration was determined in order to evaluate $\mathrm{Cu}$ extractability. As two important horticultural food crops in Asia, tomato (Lycopersicon esculentum 'Meifen No. 1') and bok choy (Brassica rapa var. chinensis 'Susheng 28') were used to investigate $\mathrm{Cu}$ phytotoxicity in a wide range of Chinese soils with and without leaching treatment, after which relationships between $\mathrm{Cu}$ phytotoxicity thresholds based on EDTA-extractions and soil properties were established. The phytotoxicity thresholds showed that biomass of bok choy was more sensitive to $\mathrm{Cu}$ than tomato. Multiple linear regression analyses showed that soil factors, including organic carbon $(\mathrm{OC})$, citrate dithionate extractable manganese (CD-Mn), cation exchange capacity (CEC), and $\mathrm{CaCO}_{3}$ explained over $85 \%$ of the variance in $\mathrm{Cu}$ phytotoxicity thresholds. The EDTA-extractable $\mathrm{Cu}$ dose-response relationships were further improved by incorporating soil properties. The new phytotoxicity predictive models indicated soil properties (soil $\mathrm{pH}, \mathrm{OC}, \mathrm{CEC}$, and oxalate-extractable $\mathrm{Mn}$ ) and EDTA-extractable $\mathrm{Cu}$ concentration explained more than $90 \%$ of the variance in the phytotoxicity response of tomato and bok choy biomass. The new phytotoxicity predictive models could be used to develop a reasonable remediation strategy for contaminated soils.
\end{abstract}

Keywords: copper; dose-response relationship; EDTA-extractability; phytotoxicity

\section{Introduction}

Continuing accumulation of copper $(\mathrm{Cu})$ in surface soils, particularly in agricultural lands, will increase the risk of phytotoxicity, and eventually threaten environment security [1]. Heavy metal accumulation in soils is of concern in agricultural production due to adverse effects on growth (due to phytotoxicity) and environmental health [2]. As an indispensable food group, vegetables play important roles in agricultural production. In recent years, research on the phytotoxicity of heavy metals to vegetables has attracted more attention. Yang et al. [3] found that for three vegetable crops (Chinese cabbage (Brassica chinensis L.), bok choy (Brassica chinensis L.), and celery (Apiumg graveolens L. var. dulce DC)) shoot growth was significantly inhibited at $\mathrm{Cu}$ concentrations above $150 \mathrm{mg} \cdot \mathrm{kg}^{-1}$ in soils. Gharbi et al. [4] found that lettuce (Lactuca sativa) and spinach (Spinacia oleracea) appeared chlorotic when it was exposed to concentrations of Cu ranging from 250 to $1000 \mathrm{mg} \cdot \mathrm{kg}^{-1}$ in sandy loam 
soils. Zhou et al. [5] reported that the presence of external soil $\mathrm{Cu}\left(100 \mathrm{mg} \cdot \mathrm{kg}^{-1}\right)$ obviously reduced the biomass of 17 bok choy (Brassica chinensis L.) cultivars more or less in the range of 25-62.7\%. However, Guo et al. [6] indicated that $\mathrm{Cu}$ toxicity varied with the soil properties.

Previous studies [3,7] have used total concentration as a regulatory criterion to assess the toxicity of heavy metals in soils, but ignored the mobile and available distinction among different heavy metal forms. There is evidence that soil properties are important factors affecting the chemical forms of heavy metals in soil [8]. For different forms of heavy metals in soils, the water-soluble plus exchangeable fractions are considered to be readily available, whereas the specific adsorbed fraction, which can be extracted by powerful chelating reagents, is potentially available and fractions bound to carbonates, iron (aluminum)-manganese ( $\mathrm{Fe}(\mathrm{Al})-\mathrm{Mn}$ ) oxides, organic matter, and minerals are generally not easily taken up by plants $[9,10]$. Therefore, models incorporating soil properties and heavy metal availability are more reasonable for predicting phytotoxicity. Previous studies indicated that soil $\mathrm{pH}$, organic carbon content (OC), cation exchange capacity (CEC), and soil texture were important factors for establishing phytotoxicity prediction models [11-13].

In soil investigations, the most frequently used method to evaluate availability is ethylenediaminetetraacetic acid (EDTA) extraction [14]. According to Sun et al. [15], the formation constant $(\log \mathrm{K})$ for 1:1 Cu-EDTA complexes at an ionic strength of 0.01 was 19.7, which was more than those for Ca-EDTA (11.6), Mn-EDTA (14.8), and Al-EDTA (16.5), indicating relatively greater stability of $\mathrm{Cu}$-EDTA in soil. The EDTA-extraction method not only considers the more reactive fractions (water-soluble, exchangeable, and specific adsorbed heavy metals) in heavy metal toxicity prediction, but also accounts for natural background concentrations in environmental risk assessment. Struijs et al. [16] pointed out that environmental risk limits for heavy metals should take into account natural background concentrations and be based on available fractions rather than total concentrations, and they developed the added risk approach to address these issues. In the Netherlands, the maximum permissible concentration, which is used for generic hazard assessment, was recommended as the sum of the available background concentration and the maximum permissible addition $[17,18]$. The EDTA-extractable concentration, which was applied to indicate the sum of available background and added metals concentrations, solved the question of how to define the available fraction of background concentration.

In the present study, three sequential EDTA-extractions were used to assess the extractability of $\mathrm{Cu}$ in order to avoid the effects of total concentration and one-step extraction. Based on EDTA-extractable concentration, the $\mathrm{Cu}$ phytotoxicity thresholds for tomato and bok choy biomass were calculated in 17 Chinese soils. Moreover, incorporating soil properties, the EDTA-extractable Cu dose-toxicity relationships for tomato and bok choy biomass were established.

\section{Materials and Methods}

\subsection{Soil Samples}

Soil samples were collected from 17 sites, which were representative of the major soil types and the distributions of soil $\mathrm{pH}$ and organic matter content of Chinese agricultural soils based on the second soil survey of 1982-1994. The detailed soil properties and treatments have been previously described by Li et al. [19]. The ranges of soil properties were as follows (Table 1): $\mathrm{pH} 4.93-9.80$, electrical conductivity $5.7-888 \mu \mathrm{S} \cdot \mathrm{cm}^{-1}$, CEC $6.36-33.59 \mathrm{cmol}^{+} \cdot \mathrm{kg}^{-1}$, OC $0.60-4.28 \%, \mathrm{CaCO}_{3} 0.5-8.92 \%$, oxalate extractable Mn (OX-Mn) 33-451 mg. $\mathrm{kg}^{-1}$, citrate dithionate extractable Mn (CD-Mn) 48-574 $\mathrm{mg} \cdot \mathrm{kg}^{-1}$, and citrate dithionate extractable iron (CD-Fe) $3729-83,920 \mathrm{mg} \cdot \mathrm{kg}^{-1}$.

Air-dried soils (0-20 cm) were sieved to $<2 \mathrm{~mm}$ and spiked with $\mathrm{Cu}\left(\mathrm{as} \mathrm{CuCl}_{2}\right.$ in deionized water) at eight rates including control treatment: 12.5, 25, 50, 100, 200, 400, and $800 \mathrm{mg} \cdot \mathrm{kg}^{-1}$ for soils with $\mathrm{pH}<5 ; 25,50,100,200,400,800$, and $1600 \mathrm{mg} \cdot \mathrm{kg}^{-1}$ for soils with $\mathrm{pH} 5-7$; and 37.5, 75, 150, 300, 600,1200 , and $2400 \mathrm{mg} \cdot \mathrm{kg}^{-1}$ for soils with $\mathrm{pH}>7$. Soil samples were then divided into two batches: one for unleached and one for leached treatments. The unleached soils were incubated for $2 \mathrm{~d}$ at 
$100 \%$ water-holding capacity and then air-dried at $25{ }^{\circ} \mathrm{C}$. Subsamples were leached with artificial rainwater to overcome potential salinity effects and to simulate natural precipitation [20]. The artificial rainwater consisted of $5 \times 10^{-4} \mathrm{~mol} \cdot \mathrm{L}^{-1} \mathrm{CaCl}_{2}, 5 \times 10^{-4} \mathrm{~mol} \cdot \mathrm{L}^{-1} \mathrm{Ca}\left(\mathrm{NO}_{3}\right)_{2}, 5 \times 10^{-4} \mathrm{~mol} \cdot \mathrm{L}^{-1} \mathrm{MgCl}_{2}$, $10^{-4} \mathrm{~mol} \cdot \mathrm{L}^{-1} \mathrm{Na}_{2} \mathrm{SO}_{4}$, and $10^{-4} \mathrm{~mol} \cdot \mathrm{L}^{-1} \mathrm{KCl}(\mathrm{pH}$ 5.9). Similar to the unleached soil samples, the leached soil samples were air-dried at $25^{\circ} \mathrm{C}$, sieved to $<2 \mathrm{~mm}$ using a plastic mesh, and stored for $<2$ months before the plant assay was conducted.

Table 1. Main soil properties of 17 Chinese sites used in the study.

\begin{tabular}{|c|c|c|c|c|c|c|c|c|}
\hline Site & $\begin{array}{l}\mathrm{pH}^{1} \\
(1: 5)\end{array}$ & $\begin{array}{c}\mathrm{EC} \\
\left(\mu \mathrm{S} \cdot \mathrm{cm}^{-1}\right)\end{array}$ & $\begin{array}{c}\mathrm{CEC}^{2} \\
\left(\mathrm{cmol}^{+} \cdot \mathrm{kg}^{-1}\right)\end{array}$ & $\begin{array}{l}\mathrm{OC}^{3} \\
(\%)\end{array}$ & $\begin{array}{c}\mathrm{CaCO}_{3} \\
(\%)\end{array}$ & $\begin{array}{c}\mathrm{OX}^{4}-\mathrm{Mn} \\
\left(\mathrm{mg} \cdot \mathrm{kg}^{-1}\right)\end{array}$ & $\begin{array}{l}\mathrm{CD}^{5}-\mathrm{Mn} \\
\left(\mathrm{mg} \cdot \mathrm{kg}^{-1}\right)\end{array}$ & $\begin{array}{c}\mathrm{CD}^{5}-\mathrm{Fe} \\
\left(\mathrm{mg} \cdot \mathrm{kg}^{-1}\right)\end{array}$ \\
\hline Haikou & 4.93 & 110.8 & 8.75 & 1.5 & $<0.5$ & 200 & 574 & 83,920 \\
\hline Qiyang & 5.31 & 74.1 & 7.47 & 0.9 & $<0.5$ & 294 & 422 & 26,154 \\
\hline Hailun & 6.56 & 153 & 33.6 & 3 & $<0.5$ & 451 & 396 & 6559 \\
\hline Jiaxing & 6.7 & 158.8 & 19.3 & 1.4 & $<0.5$ & 261 & 297 & 10,824 \\
\hline Hangzhou & 6.8 & 203.3 & 12.83 & 2.5 & $<0.5$ & 135 & 153 & 8413 \\
\hline Chongqing & 7.12 & 71 & 22.3 & 1 & $<0.5$ & 283 & 315 & 7727 \\
\hline Guangzhou & 7.27 & 136.7 & 8.3 & 1.5 & 0.15 & 33 & 48 & 11,411 \\
\hline Lingshan & 7.48 & 92.5 & 22.6 & 4.3 & 4.27 & 267 & 276 & 6950 \\
\hline Hulunber & 7.66 & 888 & 22.7 & 2.7 & 0.27 & 307 & 322 & 5259 \\
\hline Gongzhuling & 7.82 & 146.9 & 28.7 & 2.2 & 0.27 & 387 & 366 & 6932 \\
\hline Shijiazhuang & 8.19 & 302 & 11.7 & 1 & 3.84 & 222 & 261 & 7544 \\
\hline Urumchi & 8.72 & 226.5 & 10.3 & 0.9 & 5.08 & 251 & 305 & 4795 \\
\hline Yangling & 8.83 & 83.2 & 8.46 & 0.6 & 8.92 & 288 & 350 & 7193 \\
\hline Langfang & 8.84 & 5.7 & 6.36 & 0.6 & 2.42 & 74 & 112 & 3729 \\
\hline Zhangye & 8.86 & 108.7 & 8.08 & 1 & 7.75 & 121 & 166 & 4289 \\
\hline Zhengzhou & 8.86 & 151.8 & 8.5 & 1.6 & 0.15 & 233 & 331 & 8356 \\
\hline Dezhou & 8.9 & 111.8 & 8.33 & 0.7 & 6.17 & 145 & 219 & 4965 \\
\hline
\end{tabular}

${ }^{1}$ Measured in deionized water (soil: solution ratio 1:5). ${ }^{2}$ Cation exchange capacity, determined using ammonium chloride method. ${ }^{3}$ Organic carbon content, determined as the difference between total carbon [21] and inorganic carbon content [22]. ${ }^{4}$ Oxalate extractable metal [23]. ${ }^{5}$ Citrate dithionate extractable metal [24].

\subsection{EDTA-Extractability of $\mathrm{Cu}$ in 17 Chinese Soils}

The EDTA-extractability of $\mathrm{Cu}$ in 17 Chinese soils was determined using $\mathrm{Na}_{2}$-EDTA. Briefly, soil samples $\left(5 \pm 0.01 \mathrm{~g}\right.$, air-dried, $<2 \mathrm{~mm}$ ) were shaken with $25 \mathrm{~mL}$ of $0.05 \mathrm{~mol} \cdot \mathrm{L}^{-1} \mathrm{Na}_{2}$-EDTA in $50 \mathrm{~mL}$ polypropylene centrifuge tubes for $2 \mathrm{~h}$ at room temperature $\left(20^{\circ} \mathrm{C}\right)$ in a reciprocating shaker. The soil suspensions were then centrifuged at $2000 \mathrm{~g}$ for $20 \mathrm{~min}$, after which the supernatant was decanted and filtered through $0.45-\mu \mathrm{m}$ filter paper. A fresh batch of $25 \mathrm{~mL}$ of $\mathrm{Na}_{2}$-EDTA was then added to the residue to continue the extraction. The extraction steps were repeated three times. The filtrate was measured using atomic absorption spectroscopy (ZEEnit 700, Analytik Jena AG, Germany) to determine the EDTA-extractable Cu concentration in soils.

\subsection{Phytotoxicity Based on EDTA-Extractable Cu in 17 Chinese Soils}

Tomato (Lycopersicon esculentum 'Meifen No. 1'), and bok choy (Brassica rapa var. chinensis 'Susheng 28') were used to test the phytotoxicity of $\mathrm{Cu}$ in soils by biomass bioassays, according to the International Organization for Standardization [25]. Tomato and bok choy biomass were determined by cultivation in a growth chamber with $25 \pm 3{ }^{\circ} \mathrm{C}$ day and $20 \pm 3{ }^{\circ} \mathrm{C}$ night temperatures. The soil moisture content was maintained in the range of $75-90 \%$ of field capacity using deionized water throughout the growth period. Tomato and bok choy shoots were cut just above the soil surface, washed with deionized water, then dried at $65^{\circ} \mathrm{C}$ for $48 \mathrm{~h}$ and dry biomass was weighed.

\subsection{Phytotoxicity Model Incorporating Soil Properties and EDTA-Extractable Cu Concentration}

The phytotoxicity thresholds were calculated as the effective concentrations of EDTA-extractable $\mathrm{Cu}$ concentrations inhibiting $10 \%$ and $50 \%$ of plant growth (EC10-EDTA and EC50-EDTA, respectively). 
The EC10-EDTA and EC50-EDTA values, along with their 95\% confidence intervals, were derived from the fitted dose-response model [26] in Microsoft Excel (Microsoft, Redmond, WA, USA):

$$
Y=\frac{Y_{0}}{1+e^{b(X-a)}}
$$

where $Y$ is relative plant growth (\%), $X$ is the $\log _{10}$ of the effective concentrations of EDTA-extractable $\mathrm{Cu}\left(\mathrm{mg} \cdot \mathrm{kg}^{-1}\right), Y_{0}$ is the undisturbed plant growth level, $a$ is the $\log _{10}$ of EC50-EDTA value $\left(\mathrm{mg} \cdot \mathrm{kg}^{-1}\right)$, and $b$ is a curve-fitting parameter indicating the rate of increase of inhibition with increasing concentrations around the EC50-EDTA concentration. Based on the dose-response model [26], the ratio of EC50-EDTA to EC10-EDTA could be closely related to parameter $b$ :

$$
\frac{\mathrm{EC} 50-\mathrm{EDTA}}{\mathrm{EC} 10-\mathrm{EDTA}}=10^{\left(-\frac{2.2}{b}\right)}
$$

Parameter $b$, which is essential to the shape of the dose-response curve, is closely related to species sensitivity and $\mathrm{Cu}$ availability in soils. Previous studies $[19,27]$ showed that the logEC50 of $\mathrm{Cu}$ in soils could be predicted by models incorporating soil $\mathrm{pH}, \log \mathrm{OC}$, and $\log \mathrm{CEC}$. Therefore, parameters $b$ and $a$ were defined as follows:

$$
\begin{gathered}
b=f(p H, C E C, \text { Clay, } O X M n, \ldots) \\
a=K_{1}+K_{2} \times p H+K_{3} \times \log O C+K_{4} \times \log C E C
\end{gathered}
$$

where $K_{1}-K_{4}$ are fitting coefficients of the linear regression relationship between $a$ or $b$ and soil properties. Based on Equations (3) and (4), Equation (1) can be expressed:

$$
Y=\frac{Y_{0}}{1+e^{f(p H, C E C, C l a y, O X-M n, \ldots .) \times\left(X-K_{1}+K_{2} \times p H+K_{3} \times \log O C+K_{4} \times \log C E C\right)}}
$$

in which parameters $Y_{0}$ and $K_{1}-K_{4}$ can be estimated by regression analysis, conducted using the Solver Function of Microsoft Excel 2010. The parameters in the model were optimized by minimizing the sum of the square of the residual variation of the data points from the model. Relationships were deemed significant at $p \leq 0.05$.

\section{Results and Discussion}

\subsection{Phytotoxicity Thresholds Based on EDTA-Extractable Cu for Tomato and Bok Choy}

The ranges and variations of $\mathrm{Cu}$ phytotoxicity thresholds based on the EDTA-extraction (EC10-EDTA and EC50-EDTA) for tomato and bok choy biomass are shown in Figure 1. Tomato biomass showed no significant difference for EC10-EDTA and EC50-EDTA between unleached and leached soils, with EC10-EDTA values ranging within 32.4-608.8 $\mathrm{mg} \cdot \mathrm{kg}^{-1}$ and those of EC50-EDTA $81.7-1398.6 \mathrm{mg} \cdot \mathrm{kg}^{-1}$. The leaching factors, which were defined as the ratio of leached phytotoxicity threshold (EC10-EDTA or EC50-EDTA) to the corresponding unleached phytotoxicity threshold, were $1.51 \pm 0.20$ and $1.28 \pm 0.10$, respectively, similar to those reported by Li et al. [27] of $1.54 \pm 0.62$ and $1.37 \pm 0.22$, respectively, based on total $\mathrm{Cu}$ concentration. The results showed that there was the same influence of leaching on $\mathrm{Cu}$ phytotoxicity for tomato based on either available or total concentration. 


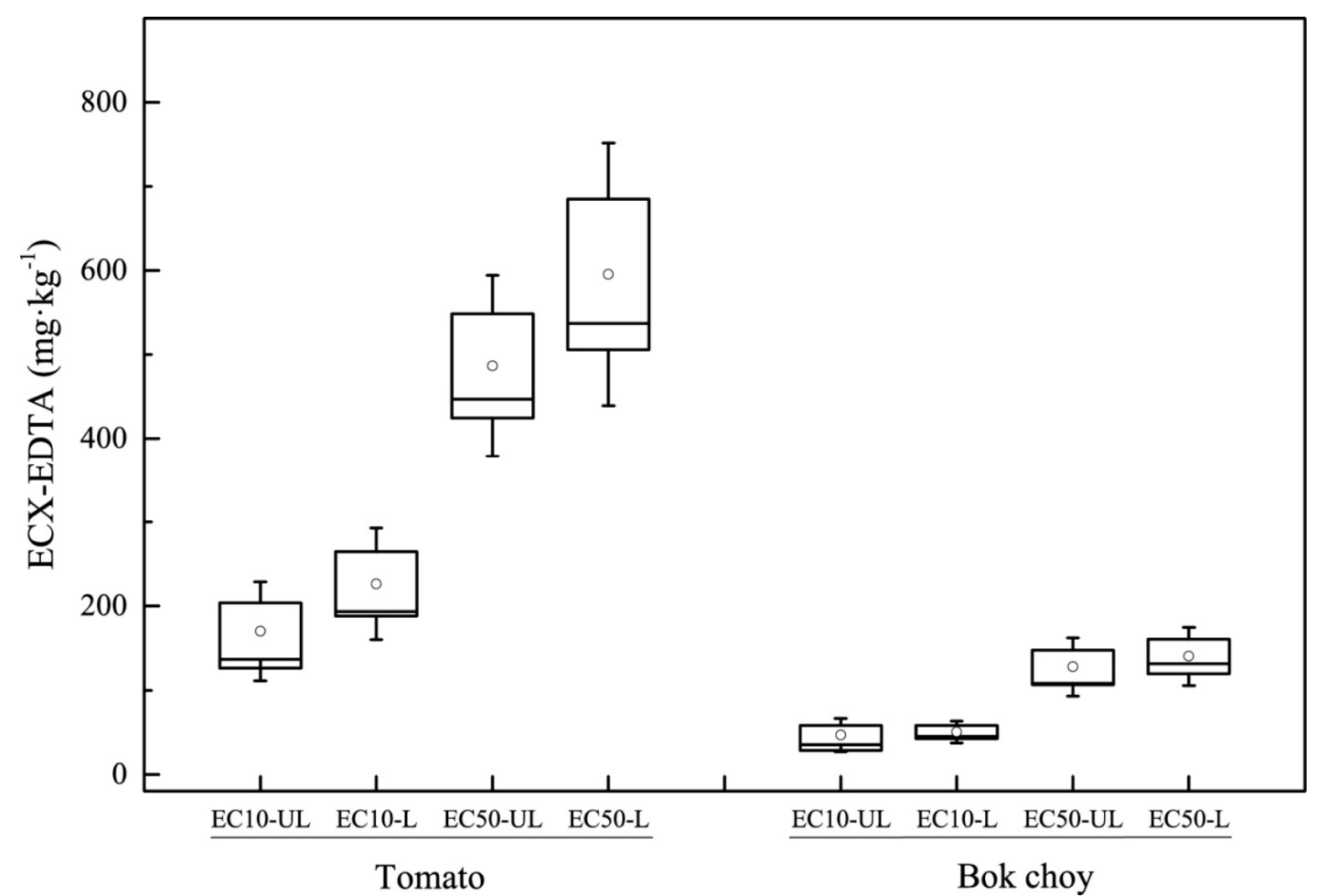

Figure 1. Ranges and variation of $\mathrm{Cu}$ phytotoxicity thresholds for tomato and bok choy growth based on EDTA-extractable concentrations in 17 Chinese soils. L = leached soils, UL = unleached soils; ECX-EDTA = effective concentration of EDTA extractable $\mathrm{Cu}$ that decreases plant growth by a user-defined percentage; EC10-EDTA = EDTA extractable $\mathrm{Cu}$ concentration in soils causing a 10\% inhibition in plant growth; EC50-EDTA = EDTA extractable $\mathrm{Cu}$ concentration in soils causing a 50\% inhibition in plant growth; The bars (I) $=10-90 \%$ confidence interval; the half box length = standard error; the line in the box = median; $\bigcirc=$ average.

For bok choy, the EC10-EDTA and EC50-EDTA values ranged within 4.5-148.5 and $33.1-290.3 \mathrm{mg} \cdot \mathrm{kg}^{-1}$, respectively, in the 17 Chinese soils without leaching. In leached soils, excluding Hunan soil, for which an appropriate dose-response model could not be fitted, the EC10-EDTA and EC50-EDTA values ranged within 11.1-120.7 and 22.1-328.6 $\mathrm{mg} \cdot \mathrm{kg}^{-1}$ for bok choy, respectively. In both unleached and leached soils, the EC10-EDTA and EC50-EDTA for bok choy were significantly higher than those for tomato biomass, indicating that bok choy was more sensitive to $\mathrm{Cu}$ phytotoxicity than tomato. According to Wang et al. [28], bok choy biomass is more sensitive to Cu phytotoxicity than tomato, which fell within the lower position of the species sensitivity distribution. It is likely that $\mathrm{Cu}$ accumulation in tissues causes inhibition of growth and reduction in the production of biomass as a general response of metal with a large number of physiological and biochemical processes [29]. As previous studies [30,31] have reported, toxic metals are easily accumulated in leafy vegetables as compared to grain or fruit crops, and most of these plants, especially Brassicaceae, grow slowly and have very low biomass productions [29]. 
3.2. Relationship Between Cu Phytotoxicity Thresholds Based on EDTA-Extractable Concentration and Soil Properties

The significant simple and multiple linear regression models to predict $\mathrm{Cu}$ phytotoxicity thresholds based on EDTA-extractable concentration (EC10-EDTA or EC50-EDTA) in relation to soil properties are presented in Table 2. For tomato, logarithms of CD-Mn and CD-Fe were found to be the best single factors in predicting EC10-EDTA and EC50-EDTA in unleached soils. According to Li et al. [27], based on total $\mathrm{Cu}$ concentration, there were poor single regression relationships between $\log$ EC50 and soil properties for unleached soil. Incorporating soil CEC into the regression model for unleached soils increased the $R^{2}$ from 0.510 to 0.677 for EC10-EDTA, but for EC50-EDTA including other soil properties did not improve the regression model. Furthermore, when CD-Mn, CEC, and $\mathrm{CaCO}_{3}$ were incorporated into the regression model, multiple linear regressions were further improved, with $R^{2}=0.852$ for EC10-EDTA, indicating that soil properties could explain $85.2 \%$ of the variance of $\log$ EC10-EDTA. The Fe(Mn) oxides in soils decreased the EDTA-extractability of Cu in soils [32] so that the phytotoxicity thresholds based on EDTA-extractable $\mathrm{Cu}$ decreased. Therefore, significant negative relationships between EDTA extractable $\mathrm{Cu}$ phytotoxicity thresholds and CD-Mn or CD-Fe were shown in the phytotoxicity predictive models. According to an analysis of soil solution by Li et al. [33], leaching removed water-soluble $\mathrm{Cu}$ and increased soil solution $\mathrm{pH}$ by up to 0.75 units because soils had a net negative charge. Therefore, both the form of $\mathrm{Cu}$ present in soil and soil properties were influenced by leaching treatment. After leaching treatment, the $\mathrm{OC}$ and $\mathrm{pH}$ became dominant factors in predicting EC10-EDTA and EC50-EDTA - with OC, as the most important single factor, explaining $51.5 \%$ and $60.1 \%$ of the variance for tomato, respectively.

A comparison of $\mathrm{Cu}$ phytotoxicity thresholds showed that bok choy was more sensitive to $\mathrm{Cu}$ than tomato. For bok choy, soil OC was the most important factor, consistent with previous results [27], and predicted $\mathrm{Cu}$ phytotoxicity thresholds in both unleached and leached soils, explaining 61.7-79.8\% and 58.5-75.7\% of the variance of EC10-EDTA and EC50-EDTA, respectively. Incorporating $\mathrm{CaCO}_{3}$ into regression models increased the $R^{2}$ from 0.757 to 0.864 and from 0.585 to 0.771 for EC50-EDTA in unleached and leached soils, respectively. Because of the weaker effect of leaching on Cu phytotoxicity for bok choy [27], the factors affecting $\mathrm{Cu}$ phytotoxicity thresholds of bok choy were the same with and without leaching treatment. 
Table 2. Simple and multiple linear regressions between phytotoxicity thresholds based on EDTA-extractable Cu and selected soil properties for tomato and bok choy biomass.

\begin{tabular}{|c|c|c|c|c|c|c|}
\hline Plant & Treatment & Regression Equation & $R^{2}$ & & $p$ & \\
\hline \multirow{9}{*}{ Tomato } & Unleached & $\log$ EC10-EDTA $=3.588-0.607 \log$ CD-Mn & 0.51 & 0.036 & & \\
\hline & $(n=17)$ & $\log$ EC10-EDTA $=3.377-0.803 \log$ CD-Mn + 0.617 log CEC & 0.677 & 0.006 & 0.04 & \\
\hline & & $\log$ EC10-EDTA $=3.305-0.990 \log \mathrm{CD}-\mathrm{Mn}+0.971 \log \mathrm{CEC}+0.057 \mathrm{CaCO}_{3}$ & 0.852 & $<0.001$ & 0.001 & 0.003 \\
\hline & & $\log$ EC50-EDTA $=5.104-0.636 \log$ CD-Fe & 0.684 & 0.002 & & \\
\hline & Leached & $\log$ EC10-EDTA $=2.139+0.725 \log$ OC & 0.515 & 0.034 & & \\
\hline & $(n=17)$ & $\log$ EC10-EDTA $=0.870+1.015 \log \mathrm{OC}+0.162 \mathrm{pH}$ & 0.737 & 0.002 & 0.011 & \\
\hline & & $\log$ EC50-EDTA $=4.931-0.577 \log$ CD-Fe & 0.523 & 0.031 & & \\
\hline & & $\log$ EC50-EDTA = $2.552+0.844 \log$ OC & 0.601 & 0.011 & & \\
\hline & & $\log$ EC50-EDTA $=1.124+1.169 \log \mathrm{OC}+0.183 \mathrm{pH}$ & 0.845 & $<0.001$ & 0.002 & \\
\hline \multirow[t]{6}{*}{ Bok choy } & Unleached & $\log$ EC10-EDTA $=1.286+1.377 \log$ OC & 0.798 & $<0.001$ & & \\
\hline & $(n=17)$ & $\log$ EC50-EDTA $=1.910+0.838 \log$ OC & 0.757 & $<0.001$ & & \\
\hline & & $\log$ EC50-EDTA $=1.775+1.092 \log \mathrm{OC}+0.043 \mathrm{CaCO}_{3}$ & 0.864 & $<0.001$ & 0.008 & \\
\hline & Leached & $\log$ EC10-EDTA $=1.526+0.690 \log$ OC & 0.617 & 0.011 & & \\
\hline & $(n=17)$ & $\log$ EC50-EDTA $=1.981+0.651 \log$ OC & 0.585 & 0.017 & & \\
\hline & & $\log$ EC50-EDTA $=1.808+0.960 \log \mathrm{OC}+0.054 \mathrm{CaCO}_{3}$ & 0.771 & 0.001 & 0.014 & \\
\hline
\end{tabular}

EC10-EDTA and EC50-EDTA, EDTA-extractable Cu concentration causing 10\% and 50\% inhibition of tomato or bok choy biomass, respectively; CD-Mn, citrate dithionate extractable Mn concentration; $\mathrm{CEC}$, effective cation exchangeable capacity; CD-Fe, citrate dithionate extractable Fe concentration; OC, organic carbon content; $p$, significance level of the factors included in the regression equations. 


\subsection{Phytotoxicity Predictive Model of EDTA-Extractable $\mathrm{Cu}$ for Tomato and Bok Choy}

The phytotoxicity thresholds (EC10-EDTA or EC50-EDTA) indicating the degree of Cu phytotoxicity were calculated by dose-response relationships between relative biomass of bok choy or tomato and EDTA-extractable $\mathrm{Cu}$ concentrations in soils. According to the description of dose-response curves by Haanstra et al. [26] (Equation (1)), $b$ is a slope parameter indicating the inhibition rate with increasing concentrations around the EC50. Additionally, the environmental conditions in the soil not only influenced $b$ but also $a$. Therefore, a simple linear correlation analysis was used to determine any significant relationship between soil properties and $b$ or $a$ in dose-response models. Based on minimizing the sum of the square of the residual variation of the data points from the models, the $b$ and $a$ incorporating soil properties are shown in Table 3.

The results of a simple linear correlation analysis showed that the most important factors affecting $a$ were soil $\mathrm{pH}, \log \mathrm{OC}$, and $\log \mathrm{CEC}$ for tomato and bok choy biomass in soils. However, for different phytotoxicity endpoints, the important factors affecting $b$ differed. Specifically, soil $\mathrm{pH}$ and OX-Mn were the most important factors for tomato biomass, but soil $\mathrm{pH}$ and clay content were most important for bok choy biomass. The absolute values of $b$ in the dose-response relationship are independent of the physiological structure of plants, but dependent on the modes of action on the biological target [34]. Moreover, Wang et al. [28] found that soil properties significantly affected $b$ values, but $b$ values among plant species in the same soil did not significantly differ. Therefore, because of the different action modes between plants and $\mathrm{Cu}$ in soil, the dose-response curve shapes differed. Both for tomato and bok choy, the soil $\mathrm{pH}$ was one important factor affecting $b$; based on Equation (2), the ratio of EC50-EDTA to EC10-EDTA depended on $b$, so the relationship between EC50-EDTA and EC10-EDTA was related to soil $\mathrm{pH}$. This result was similar to the reported quantitative relationship of different ecotoxicity thresholds for $\mathrm{Cu}$ [28], $\left(\mathrm{EC} 10=0.422 \mathrm{EC} 50-24.059 \mathrm{pH}+150.454, R^{2}=0.73, p<0.05\right)$-when soil $\mathrm{pH}$ increased, the ratio of EC10 to EC50 increased and $b$ increased. As soil $\mathrm{pH}$ increased, the curve became more gradual; therefore, the effect of increasing $\mathrm{Cu}$ dose on the toxicity response of plants was less in alkaline than acidic soils [35]. When incorporating the factors affecting $a$ and $b$, the soil properties and EDTA-extractable $\mathrm{Cu}$ dose explained $>90 \%$ of the variation of the toxicity response. The relationships between potential affecting fraction of $\mathrm{Cu}$ and EDTA-extractable $\mathrm{Cu}$ concentration based on the new dose-response curve (Table 3) are shown in Figure 2 for OC at 1\%, CEC at $20 \mathrm{cmol}^{+} \cdot \mathrm{kg}^{-1}$, and OX-Mn at $200 \mathrm{mg} \cdot \mathrm{kg}^{-1}$, indicating that at the increased EDTA-extractable $\mathrm{Cu}$ concentration, there was a higher potential effect on bok choy than tomato-thus bok choy was clearly more sensitive than tomato. The difference in sensitivity between bok choy and tomato was greater in alkaline than acidic soil. When the EDTA-extractable Cu concentration was $>100 \mathrm{mg} \cdot \mathrm{kg}^{-1}$, the same EDTA-extractable $\mathrm{Cu}$ concentration had less potential phytotoxic effect in alkaline soils for both bok choy and tomato. In other words, a limited EDTA-extractable $\mathrm{Cu}$ concentration leading to the same potential phytotoxicity effect was higher in alkaline than acidic soils. The limited value based on EDTA-extractable $\mathrm{Cu}$ concentration for a specific plant species could be calculated by the equation $X=\frac{\ln \left(Y_{0}-Y\right)-\ln Y}{b}+a$, which incorporated soil properties (Table 3). Therefore, the phytotoxicity endpoint and soil properties were critical factors in developing a reasonable remediation strategy for contaminated soils.

The model prediction effect for tomato biomass (Figure 3) showed that the predicted response reached $100 \%$ as the EDTA-extractable $\mathrm{Cu}$ concentration increased; however, compared with tomato control biomass, the measured response reached 129\% when EDTA-extractable Cu concentration was $23.65 \mathrm{mg} \cdot \mathrm{kg}^{-1}$ because of the hormesis of tomato [27,36]. Additionally, an evaluation of the tomato biomass revealed that the EDTA-extractable $\mathrm{Cu}$ dose-toxicity relationship was predicted better in unleached than leached soils. Because of the weaker effect of leaching on $\mathrm{Cu}$ phytotoxicity for bok choy biomass, the predicted effectiveness did not differ between leached and unleached treatments. 

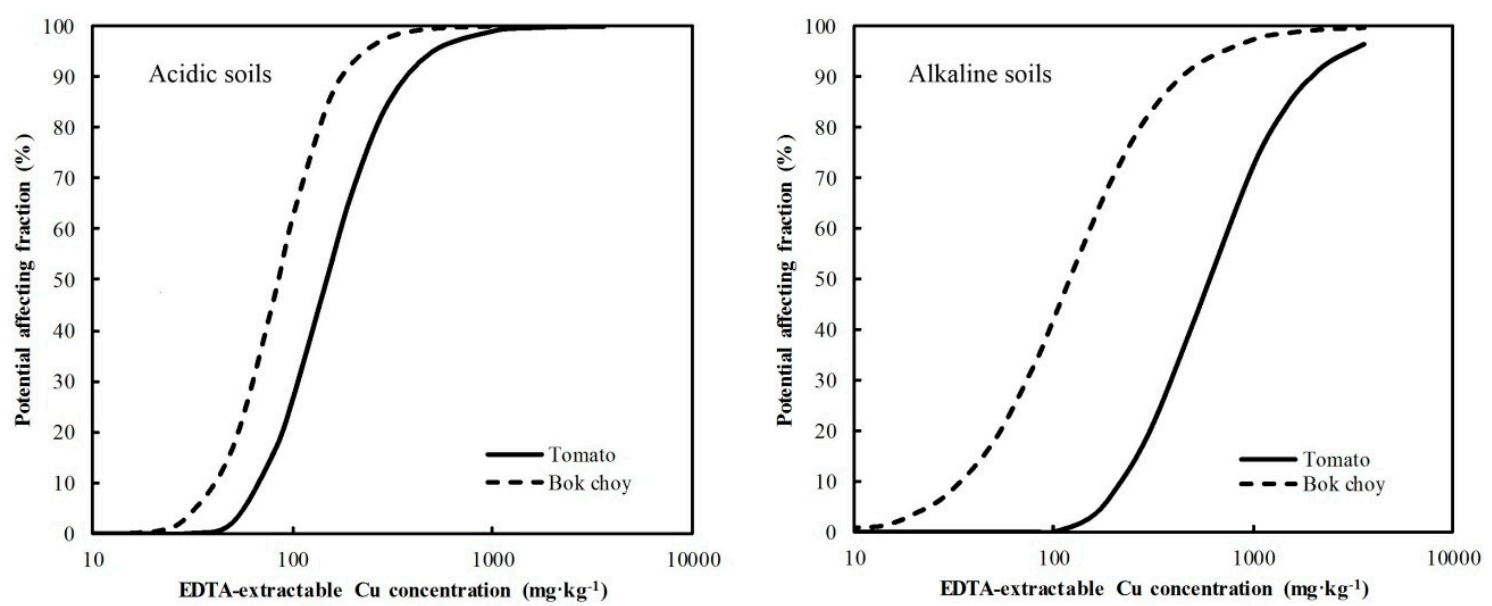

Figure 2. The EDTA-extractable $\mathrm{Cu}$ dose-toxicity curves for tomato and bok choy in acidic ( $\mathrm{pH} 5$ ) and alkaline ( $\mathrm{pH} 8$ ) soils (OC was set at $1 \%, \mathrm{CEC}$ at $20 \mathrm{cmol}^{+} \cdot \mathrm{kg}^{-1}$, and OX-Mn at $200 \mathrm{mg} \cdot \mathrm{kg}^{-1}$ ).
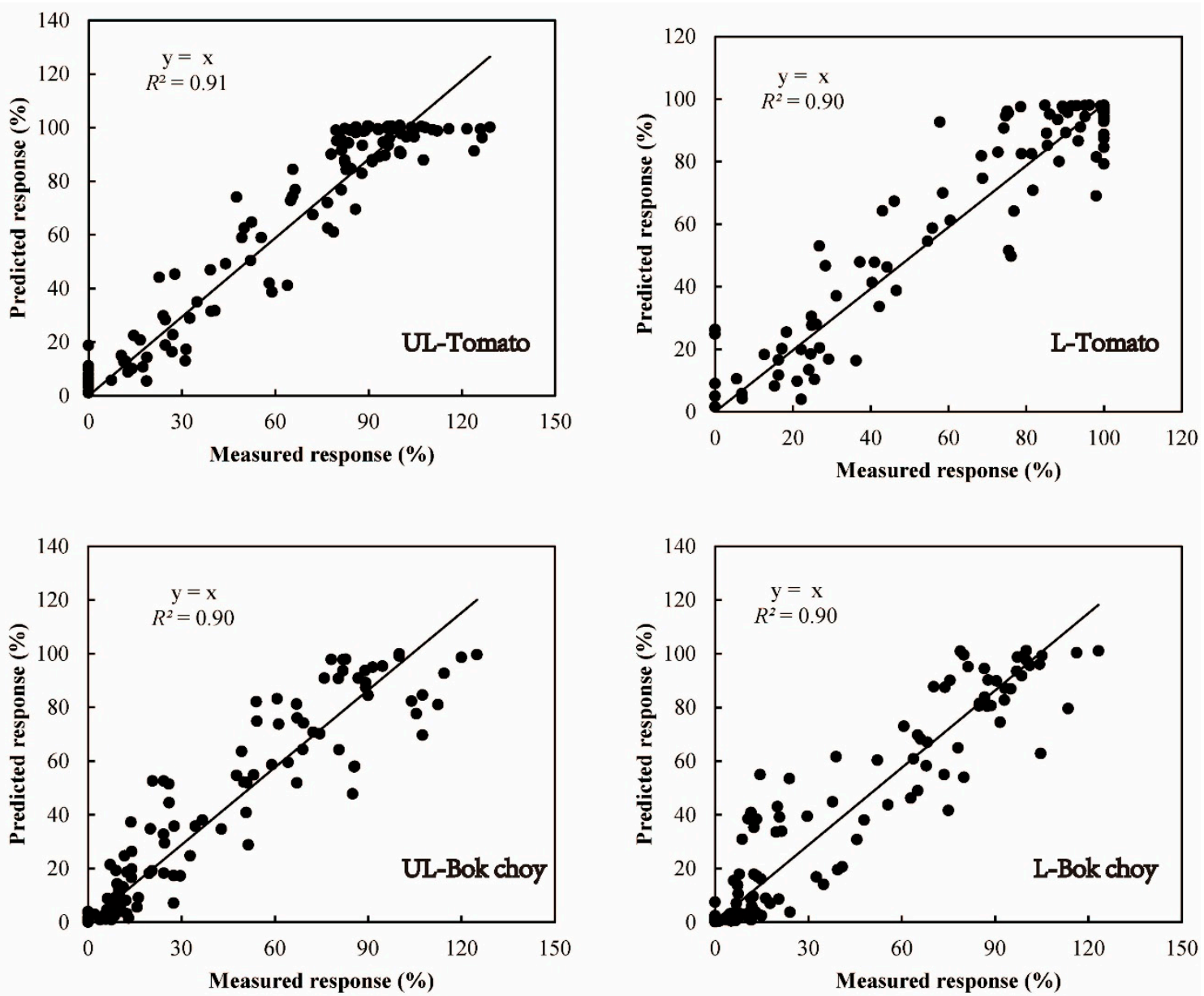

Figure 3. Measured versus predicted toxicities for tomato and bok choy biomass based on EDTA-extractable dose-toxicity relationships (see Table 3). UL and L represent unleached and leached treatments, respectively. 
Table 3. The parameters in the EDTA-extractable $\mathrm{Cu}$ dose-toxicity relationships incorporating soil properties for tomato and bok choy biomass in unleached and leached soils based on Equation (1): $Y=\frac{Y_{0}}{1+e^{b(X-a)}}$ or $X=\frac{\ln \left(Y_{0}-Y\right)-\ln Y}{b}+a$.

\begin{tabular}{|c|c|c|c|c|c|c|}
\hline $\begin{array}{l}\text { Phytotoxicity } \\
\text { Endpoints }\end{array}$ & Treatment & $Y_{0}$ & $a$ & $b$ & $R^{2}$ & $p$ \\
\hline \multirow[t]{2}{*}{ Tomato } & Unleached & 100.82 & $\begin{array}{c}a=0.63+0.21 \mathrm{pH}+0.54 \\
\log \mathrm{OC}+0.28 \log \mathrm{CEC}\end{array}$ & $\begin{array}{c}b=0.63 \mathrm{pH}+0.002 \\
\text { OX-Mn }-9.59\end{array}$ & 0.92 & $<0.01$ \\
\hline & Leached & 106.30 & $\begin{array}{c}a=0.72+0.20 \mathrm{pH}+0.71 \\
\log \mathrm{OC}+0.33 \log \mathrm{CEC}\end{array}$ & $\begin{array}{c}b=0.43 \mathrm{pH}+0.007 \\
\text { OX-Mn }-6.21\end{array}$ & 0.91 & $<0.01$ \\
\hline \multirow[t]{2}{*}{ Bok choy } & Unleached & 99.93 & $\begin{array}{c}a=1.43+0.07 \mathrm{pH}+0.99 \\
\log \mathrm{OC}-0.02 \log C E C\end{array}$ & $b=1.13 \mathrm{pH}-12.61$ & 0.91 & $<0.01$ \\
\hline & Leached & 101.09 & $\begin{array}{c}a=1.61+0.05 \mathrm{pH}+0.77 \\
\log \mathrm{OC}+0.05 \log \mathrm{CEC}\end{array}$ & $b=0.98 \mathrm{pH}-11.75$ & 0.90 & $<0.01$ \\
\hline
\end{tabular}

$Y$, relative plant growth (\%) indicating the potential affecting fraction of $\mathrm{Cu}$ on tomato and bok choy growth; $X$, $\log 10$ of the effective EDTA-extractable $\mathrm{Cu}$ concentration; $Y_{0}$, curve fitting parameter indicating undisturbed plant growth level; $a$, curve-fitting parameter indicating $\log 10$ of EC50-EDTA value; $b$, curve-fitting parameter indicating the rate of increase of inhibition with increasing EDTA-extractable $\mathrm{Cu}$ concentrations.

\section{Conclusions}

In the present study, phytotoxicity thresholds of $\mathrm{Cu}$ based on the concentrations of sequential EDTA-extractable $\mathrm{Cu}$ across a wide range of Chinese soils varied 18.8-fold for tomato and 32.9-fold for bok choy. Incorporating soil properties, the prediction model of logEC10-EDTA and logEC50-EDTA showed that CD-Fe was the most dominant factor $\left(R^{2}=0.684\right)$, followed by CD-Mn $\left(R^{2}=0.510\right)$, for tomato, and OC was the most dominant factor $\left(R^{2}=0.798\right)$ for bok choy. Furthermore, predictive models of dose-toxicity relationships for a wide range of soils based on the EDTA-extractable Cu were established in order to predict the phytotoxicity response of tomato and bok choy in Chinese soils $\left(R^{2} \geq 0.90\right)$. Based on minimizing the sum of the square of the residual variation of the data points from the models, parameters $a$ and $b$ were found to be functions of soil properties-this showed that soil $\mathrm{pH}, \log \mathrm{OC}$, and $\log \mathrm{CEC}$ were the most important factors to $a$ for tomato and bok choy biomass in soils. Because of the different action modes between plant species and $\mathrm{Cu}$ in soil, the factors affecting $b$ differed between tomato and bok choy. When incorporating factors that affected $a$ and $b$, the soil properties and EDTA-extractable $\mathrm{Cu}$ dose explained $>90 \%$ of the variation of the toxicity responses.

Author Contributions: Conceptualization: Y.M.; Data curation: B.J. and G.Z.; Formal analysis: B.J.; Funding acquisition: Y.M. and J.L.; Investigation: B.J.; Methodology: Y.M.; Project administration: Y.M.; Supervision: Y.M.; Writing—original draft: B.J.

Acknowledgments: Financial assistance was received from the Research on Migration/Transformation and Safety Threshold of Heavy Metals in Farmland Systems project by the National Key Research and Development Program of China (2016YFD0800406) and the Foundation for Safety of Agricultural Products by the Ministry of Agriculture and Rural Affairs, China (GJFP201801202).

Conflicts of Interest: The authors declare no conflict of interest. The funders had no role in the design of the study; in the collection, analyses, or interpretation of data; in the writing of the manuscript; or in the decision to publish the results.

\section{References}

1. Wu, C.F.; Luo, Y.M.; Zhang, L.M. Variability of copper availability in paddy fields in relation to selected soil properties in southeast China. Geoderma 2010, 156, 200-206. [CrossRef]

2. McLaughlin, M.J.; Hamon, R.E.; McLaren, R.G.; Speir, T.W.; Rogers, S.L. Review: A bioavailability-based rationale for controlling metal and metalloid contamination of agricultural land in Australia and New Zealand. Soil Res. 2000, 38, 1037-1086. [CrossRef]

3. Yang, X.E.; Long, X.X.; Ni, W.Z.; Ye, Z.Q.; He, Z.L.; Stoffella, P.J.; Calvert, D.V. Assessing copper thresholds for phytotoxicity and potential dietary toxicity in selected vegetable crops. J. Environ. Sci. Health B 2002, 37, 625-635. [CrossRef] [PubMed] 
4. Gharbi, F.; Rejeb, S.; Ghorbal, M.H.; Morel, J.L. Plant response to copper toxicity as affected by plant species and soil type. J. Plant Nutr. 2005, 28, 379-392. [CrossRef]

5. Zhou, D.M.; Xue, Y.; Liu, X.H.; Hao, X.Z.; Chen, H.M.; Shen, Z.G.; Si, Y.B. Responses of different pakchoi (Brassica chinensis L.) cultivars to Cu toxicity. Pedosphere 2005, 15, 9-15.

6. Guo, G.Y.; Yuan, T.; Wang, W.H.; Li, D.; Cheng, J.P.; Gao, Y.; Zhou, P. Bioavailability, mobility, and toxicity of $\mathrm{Cu}$ in soils around the Dexing $\mathrm{Cu}$ mine in China. Environ. Geochem. Health. 2011, 33, 217-224. [CrossRef]

7. Vilar, S.; Gutierrez, A.; Antezana, J.; Carral, P.; Alvarez, A. A comparative study of three different methods for the sequential extraction of heavy metals in soil. Toxicol. Environ. Chem. 2005, 87, 1-10. [CrossRef]

8. Lee, C.S.; Kao, M.M. Distribution of forms of heavy metals in soils contaminated by metallurgical smelter emissions. Environ. Lett. 2004, 39, 577-585. [CrossRef]

9. Krishnamurti, G.S.R. Chapter 20 Chemical methods for assessing contaminant bioavailability in soils. Elsevier Sci. Technol. 2008, 495-520.

10. Ma, Y.B.; Uren, N.C. Transformations of heavy metals added to soil-Application of a new sequential extraction procedure. Geoderma 1998, 84, 157-168. [CrossRef]

11. Kabata, P.A.; Pendias, H. Trace Elements in Soils and Plants, 2nd ed.; CRC Press: Boca Raton, FL, USA, 1992.

12. Micó, C.; Recatalá, L.; Peris, M.; Sánchez, J. Assessing heavy metal sources in agricultural soils of an European Mediterranean area by multivariate analysis. Chemosphere 2006, 65, 863-872. [CrossRef] [PubMed]

13. Thibault Sterckeman, F.D.; Baize, D.; Fourrier, H.; Proix, N.; Schvartz, C. Factors affecting trace element concentrations in soils developed on recent marine deposits from northern France. Appl. Geochem. 2004, 19, 89-103. [CrossRef]

14. Manouchehri, N.; Besancon, S.; Bermond, A. Major and trace metal extraction from soil by EDTA: Equilibrium and kinetic studies. Anal. Chim. Acta 2006, 559, 105-112. [CrossRef]

15. Sun, B.; Zhao, F.J.; Lombi, E.; McGrath, S.P. Leaching of heavy metals from contaminated soils using EDTA. Environ. Pollut. 2001, 113, 111-120. [CrossRef]

16. Struijs, J.; Van de Meent, D.; Peijnenburg, W.J.; Ma, V.D.H.; Crommentuijn, T. Added risk approach to derive maximum permissible concentrations for heavy metals: How to take natural background levels into account. Ecotoxicol. Environ. Saf. 1997, 37, 112-118. [CrossRef] [PubMed]

17. Crommentuijn, T.; Polder, M.; Sijm, D.; Bruijn, J.D.; Plassche, E.V.D. Evaluation of the Dutch environmental risk limits for metals by application of the added risk approach. Environ. Toxicol. Chem. 2000, 19, 1692-1701. [CrossRef]

18. Crommentuijn, T.; Sijm, D.; Bruijn, J.D.; Hoop, M.V.D.; Leeuwen, K.V.; Plassche, E.V.D. Maximum permissible and negligible concentrations for metals and metalloids in the Netherlands, taking into account background concentrations. J. Environ. Manag. 2000, 60, 121-143. [CrossRef]

19. Li, B.; Zhang, X.; Wang, X.; Ma, Y. Refining a biotic ligand model for nickel toxicity to barley root elongation in solution culture. Ecotoxicol. Environ. Saf. 2009, 72, 1760-1766. [CrossRef]

20. Oorts, K.; Ghesquiere, U.; Smolders, E. Leaching and aging decrease nickel toxicity to soil microbial processes in soils freshly spiked with nickel chloride. Environ. Toxicol. Chem. 2007, 26, 1130-1138. [CrossRef]

21. Sherrod, L.; Dunn, G.; Peterson, G.; Kolberg, R. Inorganic carbon analysis by modified pressure-calcimeter method. Soil Sci. Soc. Am. J. 2002, 66, 299-305. [CrossRef]

22. Matejovic, I. Determination of carbon and nitrogen in samples of various soils by the dry combustion. Commun. Soil Sci. Plan. 1997, 28, 1499-1511. [CrossRef]

23. Mckeague, J.A.; Day, J.H. Dithionite- and oxalate-extractable Fe and $\mathrm{Al}$ as aids in differentiating various classes of soils. Can. J. Soil Sci. 1966, 46, 13-22. [CrossRef]

24. Mehra, O.P.; Jackson, M.L. Iron oxide removal from soils and clays by a dithionite-citrate system buffered with sodium bicarbonate. Clay Clay Miner. 1960, 7, 317-327. [CrossRef]

25. International Organization for Standardization (ISO). Soil-Quality-Determination of the Effects of Pollutants on Soil Flora-Part 2: Effects of Chemicals on the Emergence and Growth of Higher Plants; ISO: Geneva, Switzerland, 1995.

26. Haanstra, L.; Doelman, P.; Voshaar, J.O. The use of sigmoidal dose response curves in soil ecotoxicological research. Plant Soil 1985, 84, 293-297. [CrossRef]

27. Li, B.; Zhang, H.T.; Ma, Y.B.; McLaughlin, M.J. Relationships between soil properties and toxicity of copper and nickel to bok choy and tomato in Chinese soils. Environ. Toxicol. Chem. 2013, 32, 2372-2378. [CrossRef] [PubMed] 
28. Wang, X.Q.; Li, B.; Wei, D.P.; Ma, Y.B.; Huang, Z.B. Cross-species extrapolation of phytotoxicity prediction models for nickel and copper added to soil. Asian J. Ecotoxicol. 2013, 8, 77-84.

29. Quartacci, M.F.; Cosi, E.; Meneguzzo, S.; Sgherri, C.; Navari-Izzo, F. Uptake and translocation of copper in Brassicaceae. J. Plant. Nutr. 2003, 26, 1065-1083. [CrossRef]

30. Haware, D.J.; Chauhan, A.; Ramteke, D.S.; Inam, F. Studies of toxic metals (Pb, Cd, Cu, Zn, Fe, Ni) content in green leafy vegetables locally available in Mysuru city, India. Int. Res. J. Environ. Sci. 2017, 6, 6-12.

31. Sharma, R.K.; Agrawal, M.; Marshall, F.M. Heavy Metal (Cu, Cd, $\mathrm{Zn}$ and $\mathrm{Pb})$ contamination of vegetable in Urban India: A case Study in Varanasi. Environ. Pollut. 2008, 154, 254-263. [CrossRef]

32. Tsang, D.C.W.; Zhang, W.H.; Lo, I.M.C. Copper extraction effectiveness and soil dissolution issues of EDTA-flushing of artificially contaminated soils. Chemosphere 2007, 68, 234-243. [CrossRef]

33. Li, X.F.; Sun, J.W.; Huang, Y.Z.; Ma, Y.B.; Zhu, Y.G. Copper toxicity thresholds in Chinese soils based on substrate-induced nitrification assay. Environ. Toxicol. Chem. 2010, 29, 294-300. [CrossRef] [PubMed]

34. Chaperon, S.; Sauve, S. Toxicity interaction of metals ( $\mathrm{Ag}, \mathrm{Cu}, \mathrm{Hg}, \mathrm{Zn})$ to urease and dehydrogenase activities in soils. Soil Biol. Biochem. 2007, 39, 2329-2338. [CrossRef]

35. Guo, X.Y.; Zuo, Y.B.; Wang, B.R.; Li, J.M.; Ma, Y.B. Toxicity and accumulation of copper and nickel in maize plants cropped on calcareous and acidic field soils. Plant Soil 2010, 333, 365-373. [CrossRef]

36. Schabenberger, O.; Tharp, B.E.; Kells, J.J.; Penner, D. Statistical tests for hormesis and effective dosages in herbicide dose response. Agron. J. 1999, 91, 713-721. [CrossRef]

(C) 2019 by the authors. Licensee MDPI, Basel, Switzerland. This article is an open access article distributed under the terms and conditions of the Creative Commons Attribution (CC BY) license (http://creativecommons.org/licenses/by/4.0/). 